\title{
CONSTITUTIONAL STRUCTURES FOR A STRONG DEMOCRACY: CONSIDERATIONS ON THE GOVERNMENT OF PAKISTAN ${ }^{1}$
}

\author{
by Roger Myerson, University of Chicago
}

Abstract. For democracy to prosper in Pakistan, structural reforms to strengthen democratic competition could be vital. This paper considers some suggested reforms, using ideas from economics of oligopolistic competition and game theory. Successful democracy is based on a flexible system of strong political parties and a plentiful supply of politicians who have good reputations for responsible democratic leadership. Unimpeded parliamentary responsibility for government helps develop strong parties. National parties should be able to nominate candidates in all elections, including local elections and tribal areas. For a flexible party system, members of the National Assembly should be free to form new parties, not restricted by sanctions against floor-crossing. With federalism, provincial and local democracy also reduce political entry barriers, as politicians can prove their qualifications for higher office by responsible service at lower levels of government. Electing responsible local councils by approval-voting open-list proportional representation can strengthen the local base of democratic leadership in all communities. In single-seat districts of provincial and national assemblies, the use of runoff elections would allow more flexible party competition. Democratic political ties with neighboring nations could extend Pakistan's regional influence to help consolidate democracy.

\section{Introduction}

How can constitutional reforms improve the chances for successful democracy? The importance of this question has never been greater anywhere in the world than in Pakistan today. It demands our best efforts to answer it, but we do not know enough. Democratic constitutional structures can differ in a bewildering variety of dimensions, each of which can subtly affect the incentives of political leaders. In this paper, I consider some of the important constitutional questions that face Pakistan today. I try to offer some specific suggestions, based on economic and game-theoretic analysis, but I cannot claim to have proven optimality of any suggestion here. Indeed, an American author cannot offer anything but general analytical principles and tentative suggestions to great political questions in this country. But these questions are so important, to Pakistan and to the world, that we must all offer our best analytical efforts to study them. ${ }^{2}$

My hope is that the suggestions here may be worthy of serious consideration by

\footnotetext{
${ }^{1}$ This paper was written for presentation at Lahore University of Management Sciences on April 7, 2009, and it has been profoundly influenced and improved by comments and suggestions from Adnan Khan, Ali Cheema, and Asim Khwaja. The author gratefully acknowledges their help but accepts all responsibility for any errors that remain.

${ }^{2}$ Since this paper was written, Pakistan has ratified the 18th Constitutional Amendment (2010), which addresses some of the concerns that are discussed here. Indeed, this paper was originally written with the hope that it might contribute to the broad discussion that led to this amendment. But the issues of constitutional design that were raised in this discussion and that are covered in this paper should remain relevant to democracies throughout the world.
} 
concerned citizens of Pakistan, and that such consideration may help to extend the focus of political debate. Readers may find merit in some of my arguments and may disagree with others, but I hope that a reader who considers carefully his reasons for disagreeing may thereby gain a deeper understanding into the vital constitutional questions that face this country today.

To think about democratic political competition, we can begin with ideas that economists have developed for studying competition in markets. Political parties or factions are suppliers of government services to the public in the political market, but profits to political suppliers are generally called corruption. In a nondemocratic one-party state, the ruling faction has a political monopoly and can extract such corruption-profits from the general public, like the monopolistic supplier of any essential service. The basic rationale for democracy is that political competition should motivate democratic political parties to offer their constituents better public service at a lower corruption-price.

National democracy can never approximate the economic ideal of perfect competition, however. The difficulties of assigning distinct accountability for many aspects of public policy severely constrain the ways that public power can be divided among different independent suppliers. National government is too complex to be entrusted to any group that has no proven record of administrative competence. Smooth transitions of power require that outgoing parties should have some hope of returning to power, provided that they do not abuse their power at the end. For all these reasons, national democratic competition can never involve more than a relatively small number of serious political parties. So it may be misleading to describe democracy as "government by the people"; instead we should see democracy as government by political parties which must compete for popular approval. In terms of economic analysis, democratic competition should be understood as a kind of imperfect oligopolistic competition, in which several large suppliers may expect to earn profits that are positive but less than what a monopolist could take.

There are several general lessons of oligopoly theory that may be taken from economics to the analysis of democratic systems. In the short run, given the terms that other suppliers are offering to the public, any one supplier's competitive incentive to offer better service at a lower price depends on the elasticity of demand that the supplier faces. In the longer term, however, if the set of suppliers is fixed, then they could try to establish a collusive agreement to share monopoly profits among themselves, deterring competitive deviations by threats of competitive 
responses that would reduce profits for all of them. Such collusive agreements are difficult to sustain, however, if the elevated profits would attract new competitive suppliers to enter the market. So the level of profit-taking by suppliers in a long-term equilibrium may ultimately depend on barriers to entry against new competitors. In general, these demand elasticities and entry barriers can depend on many details of market structure, which can thus affect the competitive conduct of oligopolistic suppliers and their performance in serving the public.

So the effective force of competition in a democracy may depend on structural details of the constitutional system. The elasticity of demand for a political party is its possibility of gaining or losing offices in future elections, and such possibilities depend on the division of power among offices in different levels or branches of government. Barriers to entry are lowered when more political leaders have independent opportunities to demonstrate their governing capacity, and such opportunities are regularly found in independently elected provincial governments of federal democracy, and in ministries of multiparty parliamentary government. Thus, federalism and multiparty parliamentary government can enhance the competitiveness of democracy.

Although the basic purpose of democracy is to compel politicians to compete for the benefit of the public, democratic constitutional structures are principally designed by politicians who are not normally interested in making the system more competitive for themselves. But in this regard, the difficult circumstances in Pakistan today may contain a deep source of hope, as leaders in all major parties understand now that the survival of democracy itself depends on the public seeing some real benefits from democratic government. So today, Pakistan's democratic politicians and voters may all share a stake in reforms that can make democracy more competitive.

The suggestions that are considered here may be grouped into two categories: provisions that can foster a flexible system of strong political parties at the national level, and provisions that can extend the supply of democratic leadership more deeply to provincial and local levels. Democracy begins with political options being offered to voters, and so my review of constitutional questions begins by considering the nomination of candidates by parties and the formation of parties by coalitions in the National Assembly. Then I review the advantages of parliamentary government for developing strong cohesive national parties. After noting that a democratic system based exclusively in one assembly could be very susceptible to collusion, I 
then discuss the importance of a federal division of powers, which creates autonomous units of government where more politicians can prove their qualifications for leadership. I then focus at length on how to design local elections so that parties will build a stronger base of local democratic leadership, which can become the primary point of entry for new political talent. I next review the problem of entry barriers against third parties in plurality elections for provincial and national assemblies. Finally, broader regional ties are briefly discussed.

\section{Nomination of candidates and formation of parties}

A system of democratic political competition must be ultimately based on two kinds of fundamental democratic rights: the rights of voters to elect their representatives by freely choosing between candidates nominated by different parties, and the rights of politicians to organize parties that nominate candidates for election.

The basic democratic incentive for leaders to improve government services for the public cannot apply to members of the public who lack the right to choose freely between candidates of different parties. The argument for universal adult suffrage is derived from this basic fact. It is easy to see how established local leaders might induce some of their clients to testify against the extension of full voting rights into their community. But when voting rights are limited or denied for any group, members of this group will be exposed to greater risks of being ignored or ill-served or exploited by their leaders. This argument strongly suggests that individuals' rights to vote and political parties' rights to compete should be extended fully to the Tribal Areas, as to all other parts of the nation. ${ }^{3}$ An individual's right to vote is incomplete without the right to have major political parties competing for this vote. So nothing should prevent any national political party from nominating candidates in all elections throughout the nation, as long as the party is endorsed by at least some minimal number of members of the National Assembly (say, more than $1 / 8$ of the Assembly). In particular, rules that have prevented political parties from sponsoring candidates in Tribal Areas and in local elections should be repealed.

The integrity of elections can be more strongly defended when two or more national parties have a recognized stake in their rights to nominate competitive candidates. Democracy

\footnotetext{
${ }^{3}$ It is difficult to see any fundamental reason why normal legal and political rights have been denied to people in the Tribal Areas, other than to create an ill-governed space from which guerrilla forces could destabilize Afghanistan. Certainly such destabilization has been the result for decades, and thus the costs of this policy have extended far beyond these poor border areas.
} 
has sometimes been undermined by abuses of nomination rules, for example in some Russian provincial elections, by disqualifying opposition candidates, or by adding similarly-named candidates to confuse their supporters. Konitzer (2006) has argued that such abuses depended on the absence of strong competitive parties in Russian democracy. A national party should have an interest in maintaining a national reputation for resisting such abuse of democratic rules, which could undermine the party's ability to compete democratically for power. A political party clearly needs a reputation for defending its own candidates' rights to compete freely and fairly in elections, but its national reputation could also be tarnished if it tolerated such abuse by local officials whom it has sponsored.

This essential investment in the democratic process can be strengthened when party leadership is based in an elected assembly. When party leaders owe their positions to success in popular elections, they have a direct personal stake in maintaining the system of electoral competition. Members of a legislative assembly regularly develop working relationships that cross party lines, and such connections can help members of the assembly to identify their shared interest in maintaining a system of elections in which they all can compete fairly. Thus, as suggested by Benazir Bhutto and Nawaz Sharif's Charter of Democracy, election commissions should be constituted with transparent and effective input from all major parliamentary parties.

For a flexible system of parties based in the National Assembly, with low entry barriers, members of the National Assembly should be free to form new political parties. Unfortunately, the right of elected representatives to change parties is restricted under Article 63A in Pakistan's constitution. I would suggest that this provision, from the 14th amendment, may deserve serious reconsideration. This amendment may have been justified by an intention to prevent members of the National Assembly from being corruptly induced to undermine the governing coalition by changing their votes. But by limiting the freedom for MNAs to make independent political decisions, this article concentrates more power in the hands of a few party leaders and makes it harder for National Assembly to generate new political coalitions.

The adverse effects of Article 63A could be somewhat mitigated by requiring that a party's action against a defecting member should be approved by a supermajority (say 2/3) of the party's members in the National Assembly, and by allowing any defecting members to retain their seats until a by-election is held in their district, where they should have a right to run for reelection as independents or members of another party. Thus modified, the article would apply 
only against defecting votes that would not be approved by the member's constituents. In any case, this article should not provide sanctions that deter members of the Assembly from endorsing a new party and carrying its banner in future elections.

Given that corrupt floor-crossing transactions must involve a rival party leader as well as the defecting MNA, one could also suggest, as an alternative, that the prime minister's oath of office might include a pledge that he has never recruited any parliamentary support by bribes or threats. In the long run, however, there is a more reliable deterrent. A politician cannot hope to win free elections without a reputation for reliably fulfilling promises to the voters, and the need to maintain this reputation should be the essential deterrent against selling public parliamentary votes for corrupt private benefits.

\section{Advantages of parliamentary government}

Pakistan's 1973 constitution has been written as a parliamentary system, in which executive authority is exercised by ministers who are responsible to the National Assembly. This constitutional choice seems wise, as evidence indicates that vesting executive authority in a popularly elected president can significantly increase the risk of democracy breaking down. ${ }^{4}$ Any government is sustained by the work of many political agents who must have general confidence in their leadership, but presidential democracy overlays an assumption that one leader can create a government by his personal mandate from the population at large. When a president is tempted to rely on this personal mandate instead of maintaining broad political support, the result is to weaken party discipline or convert it into personal loyalty.

Parliamentary responsibility requires that the leadership of a governing coalition must be based in the National Assembly. Parliamentary democracies have stronger and more cohesive political parties, because back-benchers in the parliament know that their party leaders cannot hold power without maintaining their confidence, and so parliamentary leaders can make more credible long-term promises to motivate party discipline. Thus, as we look for ways to sharpen democratic competition among parties, we should appreciate the way that a parliamentary system helps to make the parties more coherent and more firmly based in the elected assembly.

Another advantage of parliamentary systems may be seen in the political crises that occur

\footnotetext{
${ }^{4}$ Przeworski et. al. (2000 p. 130), and Boix (2003, p. 154) have observed average annual failure rates of about $4 \%$ among presidential democracies but only $1 \%$ among parliamentary democracies.
} 
when a senior political leader suffers a personal scandal or is convicted in a court of law. A presidential system can make such crises even more severe, because it is very difficult constitutionally to replace a popularly elected president before the end of his term, even after he has lost most of his political support. Under a parliamentary system, in contrast, the ability of a party or coalition to exercise government authority should not be affected by the personal problems of one leader. From this perspective, it seems that a court's conviction of Punjab's chief minister should have been less problematic for democracy than the centrally-appointed governor's subsequent action to take power from the governing coalition in the province (as occurred in early 2009).

In a parliamentary democracy, the president is supposed to serve as a nonpolitical head of state, above the process of parliamentary coalition-building. To fulfill this role, it is essential that the president must not interfere with the ability of a majority coalition in the National Assembly to give its chosen ministers full authority over all executive agencies of the national government. The constitutional requirement (from Article 48-(1)) that the president must act only in accordance with the advice of the prime minister or cabinet should be consistently applied to all executive functions of the president. In this regard, the most problematic section may be Article 58-2(b), which allows the president to dissolve the National Assembly even when its cabinet retains the confidence of a parliamentary majority. The mere threat to apply this power could be used by a president to coerce leaders of the National Assembly. So the basic principle of parliamentary sovereignty provides substantial reasons for recommending that this clause 58-2(b) be repealed. ${ }^{5}$ If it were not, I would suggest that it could be mitigated by adding a requirement that, when a president invokes this clause to dissolve the National Assembly, the president must also resign his own office within 120 days, unless his act of dissolution is validated by a majority vote in the new National Assembly after the general election. ${ }^{6}$ With this modification, a president would be unlikely to use this clause against a parliamentary majority unless he expected his action to get broad popular support in the subsequent election.

To strengthen the party system at all levels, I would suggest that the principle of parliamentary responsibility can be equally recommended for provincial and local governments, just as at the national level. Under this principle, a provincial chief minister or local nazim

\footnotetext{
${ }^{5}$ Since this paper was written, Articles 48 and 58 were indeed amended in 2010 by the 18 th Amendment.

${ }^{6}$ Here 120 days is the sum of the 90 days allowed for a general election to the national assembly in Article 48 plus the 30 days allowed for electing a president after a general election in Article 41 .
} 
(mayor) should exercise executive authority only with the confidence of a majority in the respective assembly or council. If the difficulties of coalition formation seem problematic, the governing coalition could be given more stability by requiring (as in Germany) that parliamentary votes of no-confidence must be constructive, that is, that any motion of noconfidence must also name a new leader (prime minister, chief minister, or nazim) to form the next government.

There may be risks from basing national political competition too exclusively in the national assembly, with its strong parliamentary parties. If entry into the democratic arena is only through the national assembly, then the major factions of the assembly could maintain a collusive agreement to share the benefits of power among themselves and avoid costly competition to better serve the public. (The French Fourth Republic, for example, has been seen as a case where the concentration of political power in one assembly may have allowed democratic politics to become less focused on interests of the public.) Competitive democracy needs some other route for candidates to enter the national political arena. In a federal democracy, provincial and local governments can provide such alternative routes for competitive entry into national politics.

\section{Federal division of powers}

Federalism is widely admired by political scientists. ${ }^{7}$ From our perspective, the significant political benefits of federalism are in the ways that it affects democratic competition. For example, a regional ethnic group's identification with one political party can be broken by the development of multiparty competition in provinces where this group is predominant. Most importantly, provincial and local democracy in federalism can make national democracy more competitive by lowering barriers to entry into national politics.

In a federal democracy, if corrupt noncompetitive government was generally expected at both national and provincial levels, then a provincial leader who provides better public service could become a serious contender for national political power. Thus, provincial democracy can make national democracy more competitive, by creating more opportunities for independently

\footnotetext{
${ }^{7}$ For a contrary view, see Triesman (2007), who questions some common reasons for advocating federalism. He cogently argues that the national leadership of a unitary state could just as well apply different government policies in different provinces, to accommodate regional differences, or to find better policies by local experimentation.
} 
elected politicians to demonstrate their abilities to govern. (See Myerson, 2006, for a rigorous formulation of this argument.)

Similarly, elected members of local councils who improve public service in their local government can develop reputations that make them stronger candidates for power at the provincial level. Thus in a federal system, local, provincial, and national democracy should create a natural ladder on which politicians can hope to advance by providing better public service. That is, the possibility of democratically advancing to higher levels of power in a federal system increases the elasticity of political demand for politicians at each level below the top, and thus it increases their competitive incentives to offer better public service.

This principle of democratic advancement in federalism may sometimes seem to threaten the interests of established national leaders. When top political leaders fear potential rivals from below, they may prefer to exercise direct political control over lower levels of government, to make political advancement from lower levels depend more on demonstrations of loyalty to superiors than on service to the public. ${ }^{8}$ But a party can be competitively weakened if its leaders try to regulate advancement within the party in this way. The party's competitive strength depends on its local agents' efforts to win popular support, and their incentive to win such support by local public service is increased by the principle of democratic advancement. Thus, although the competitive pressures of local democracy may sometimes seem to threaten the short-term interests of some party leaders, local democracy can strengthen a party in the long run, by providing a better measure of how successful its local agents are in winning popular support. However, back-bench members of the national and provincial assemblies may also have some incentive to resist any devolution of power to locally elected councils, which could compete with the assembly representatives as local distributors of political patronage.

At the end of General Pervez Musharraf's regime in 2008, Pakistan had an established framework for democracy at the local, provincial, and national levels. Although local elections were introduced during the period of military rule, ${ }^{9}$ my analysis would suggest that local

\footnotetext{
${ }^{8}$ Michels (1915) called this the "iron law of oligarchy."

${ }^{9}$ Bardhan and Mookherjee (2006) cite several cases where military rulers have introduced local democracy, perhaps to gain some democratic legitimation for their regime. Local elections may be more readily manipulated by a military ruler when national democratic parties have made no previous efforts to cultivate local democracy. Regardless of the ruler's original motives, the introduction of local democracy can strengthen the foundations for national democracy in the long run.
} 
democracy can greatly strengthen the entire democratic system and so should be maintained. ${ }^{10}$ But local democratic competition under the Musharraf regime was weakened by restrictions against parties' participation in local democracy. The rights of national parties to sponsor alternative candidates in local elections can be vital to sustaining local democracy. In all countries, local governments can often become dominated by one local leader, but such local bosses should know that, if they fail to provide good public services to the voters, then they could face serious challengers sponsored by a rival national party.

Conversely, any party that is endorsed by at least some minimal number of members of a provincial assembly should be able to nominate candidates for any election in the province, including the election of National-Assembly representatives for districts in the province. Such potential for provincially-based parties is essential for provincial democracy to create autonomous routes for new parties to enter into national politics.

Officials of local and provincial governments must be subject to higher national law, but local and provincial governments must also have some constitutional protection against selective politically-motivated interference in their domain. There is always a risk that national leaders may be tempted to use the power of the national government to undermine a provincial or local leader who is seen as a potential political rival. In some countries, leaders of the national government may try to exercise control over provincial governments, by threats of budgetary reductions and administrative actions against provinces that are controlled by political rivals of the national leadership. But the political benefits of federalism depend on voters having the right to entrust their local and provincial governments to local leaders who may become rivals for higher national power. So it is important that some scope of administrative and budgetary authority for provincial and local governments should be defined and protected by the constitution.

The constitution of Pakistan includes provisions that define separate administrative responsibilities to the national and provincial governments. From our perspective here, it is only essential that the scope of administrative and budgetary authority for provincial governments should be substantial enough that a record of successful leadership in provincial government can be a strong qualification for national leadership. For democratic accountability, the scope of

\footnotetext{
${ }^{10}$ Sadly this remark has become obsolete since it was written in April 2009. The locally elected councils that had been established under military rule in 2001 were dissolved by Pakistan's civilian leaders in late 2009. See Cheema, Khan, and Myerson (2010).
} 
responsibility for each level of government needs to be clear, and so it may be desirable to keep the concurrent list small. It can be suggested also that the constitution should similarly define and protect a scope of authority for elected local governments.

The integral autonomy of a local or provincial government requires that its administrative staff must know that their long-term careers are dependent on the elected leaders of the unit of government that they serve, not on a wider government bureaucracy. Agents of higher levels of government should not directly interfere in the administrative work of provincial or local governments within their constitutionally mandated domains. As a general principle, legal actions by the national government against lower levels of government should require some independent sanction, either from an independent judiciary ${ }^{11}$ or from the voters. When a provincial government is in crisis, for example, this principle could support Pakistan's centrallyappointed governors having powers to call new provincial elections, but not to take direct control of the provincial government without giving voters an opportunity to judge.

Provincial budgets should not be subject to political manipulation by federal officials. Under the constitution, rules for distributing revenues to provincial governments are to be formulated by the National Finance Commission at 5-year intervals. Given the vital importance of these budgetary distributions, the commission's work will inevitably require difficult compromises, as there is no perfect formula. The essential requirement is to establish a distribution rule that is transparently verifiable, so that budgetary deviations from this rule can be publicly scrutinized for any indication of the federal budget being used to influence provincial politics.

One potential risk of federalism is that it can exacerbate threats of regional secessionism. $^{12}$ This risk is greatest when individual provinces are large enough to be viable as

\footnotetext{
${ }^{11}$ This paper's focus is on democratic competition for political power, not on the judiciary. Still we should recognize the vital importance of an independent judiciary, in which professionally committed individuals, without other administrative responsibilities or powers, must examine and judge compliance with the law in government and society. But who will judge the judges? Ultimately, the public must be able to judge the integrity of the judicial system. So no part of government has greater need for transparency than the judiciary. Article 204-2(b), which forbids anyone from doing anything to bring a judge into contempt, can seriously inhibit public scrutiny of judicial decisions, and one may strongly suggest that it should be repealed. Freedom of speech and the press, guaranteed in Article 19, are vital for reducing political barriers to entry. They should not be abridged with regard to the judiciary.

${ }^{12}$ See also Brancati (2006), who argues that decentralization is less likely to cause secessionism in a political system that has strong national parties. This observation should reinforce our focus on parliamentary structures that can foster a flexible system of strong national parties.
} 
independent states, so that a provincial leader could be tempted by the possibility of becoming the leader of a sovereign nation. The straightforward remedy for this risk, I would suggest, is to have smaller provinces. From our perspective, decreasing the size of provinces increases the number of opportunities for different provincial leaders to demonstrate their ability to offer good government, and so it can also make democracy more competitive. It is essential only that individual provinces should be large enough that a record of successful provincial leadership can be recognized evidence of a politician's qualifications for higher national leadership.

It is always politically difficult to consider changes of provincial boundaries, because so many politicians have vested interests in the existing structures. (In Pakistan's constitution, Article 239-(4) specifies that a constitutional amendment that would alter the limits of a province must be passed by a $2 / 3$ vote in the provincial assembly as well as in each house of parliament.) But a subdivision of Pakistan's largest provinces might not have much effect on the distribution of power among the major political parties, as each party could expect to retain power in most parts of the provinces that it currently controls. So there may be some hope that the question of increasing the number of provinces could be seriously considered in Pakistan today. It would seem potentially important. Pakistan inherited its provinces historically from the much larger British Raj, and now Punjab alone includes about half of Pakistan's population. Even when separatism is not in question, the prospect of one provincial government having power over so much of the nation creates political tensions that can destabilize democracy. (See Hale, 2004.) Provincial leaders should be able to challenge national leaders democratically, by providing better public service in their province, but not by contesting the national government's authority over so much of the nation. As a general rule, one might suggest that no province should include more than $20 \%$ of the national population.

\section{Systems of election for local councils}

The electoral system is an essential component of the political game by which power is allocated in a democracy. We should consider features of electoral systems in some detail, because electoral rules can fundamentally influence the competitive conduct of politicians and ultimately the performance of democratic government. (See also Myerson, 1999.)

Under Pakistan's local government reforms since 2000, local union councils have been popularly elected by a voting rule called single non-transferable vote or SNTV. (See Keefer, 
Narayan, and Vishwanath, 2006; and Cheema, Khwaja, and Qadir, 2006.) SNTV is a kind of multi-seat proportional representation system, but each voter must cast a ballot that endorses one single candidate. There is no option to vote for any party list; each voter must choose one individual candidate among those available for the seats. Historically, SNTV was introduced in Japan in 1900 by oligarchic rulers who had an interest in keeping democracy weak (Ramseyer and Rosenbluth, 1998), and it is important to understand how it can do this.

Under Pakistan's original local-election system from 2000, for example, a voter could cast one vote for a candidate to fill the 8 general unreserved seats on the council, plus separate votes for several other categories of reserved seats for women, minorities, and disadvantaged groups. To see the problems with SNTV, imagine that two factions are competing to control the council, and each has nominated enough candidates to take a majority of the council. Suppose that one faction is preferred by a majority of voters, but this faction has not organized its supporters or directed them how to vote. Without organizational discipline, it could easily happen that most of this faction's supporters might give their general-seat votes to the faction's most popular candidate. Then the other faction could win all the other general seats, even with support from less than half of the voters, by organizing its supporters into 7 equal-sized subgroups and directing each group to cast its ballots for one of 7 candidates for the faction. Such a victory for the minority faction would depend on its leaders knowing accurately how many supporters they have in each subgroup, and on these supporters being ready to obey their leaders' directions about how to vote.

Thus, in the contest for power, SNTV favors factions that have supporters who will obey their leaders' coordinating directives about how to vote. So SNTV tends to reinforce the power of corporate or tribal leaders who exercise authority in patron-client relationships. Democratic elections are supposed to be opportunities for people to choose their leaders, but this basic function of democracy is undermined when SNTV compels voting blocs to identify their coordinating leadership before the election.

These coordination problems under SNTV become more severe when the number of seats being allocated is larger. So the problems of SNTV may have significantly contributed to the decision in 2005 to decrease the size of the local union councils from 21 to 13.

This bias against less-organized groups of voters can be eliminated by changing to a proportional representation system in which people vote for an entire party list, so that the list 
that is endorsed by the most voters will always get the most seats. ${ }^{13}$ But if people can only vote for a party list, than there is no electoral competition between members of the same party list (as the party's leadership decides how the party's seats are allocated among its listed candidates). For intra-party democracy, I would suggest, it may be better to use an electoral system in which people can vote both for a party and for individual candidates within the party's list. Under such an open-list proportional-representation system, seats are allocated to each party in proportion to the total number of voters who support it, and then the seats of each party are given to the candidates in its list who get the most individual votes.

In the open-list proportional-representation system that is used in Brazil, for example, a voter must name one candidate on one party's list. (See Ames, 2001.) So the Brazilian system looks very similar to SNTV, in that each voter expresses a preference for one individual candidate. But in the Brazilian open-list system, a party's supporters can make independent uncoordinated choices among the candidates in the party's list without affecting the total number of seats that the party gets. Thus, the Brazilian open-list system seems a clear improvement over the single non-transferable vote system that has been used in Pakistan's local council elections (and in Afghanistan's legislative elections).

When a voter can support only one individual politician, however, the voter becomes dependent on this politician to represent the voter's interests. So like SNTV, the Brazilian rule of voting for only one individual candidate can reinforce patron-client relationships of political dependency.

The unique-dependency problem can be solved, I would suggest, by allowing each voter to express approval for any number of candidates in the party list that he supports. Under such an approval-voting open-list system, after each party gets seats in proportion to the number of voters who support it, then the party's seats are allocated to those among its candidates who are approved by the largest numbers of party supporters. In contrast to the Brazilian single-vote system, which encourages each candidate to cultivate a small bloc of voters who look exclusively to him for representation, this approval-voting system encourages all candidates in a

\footnotetext{
${ }^{13}$ We need a formula for approximating proportionality in a council with a finite number of seats. A good commonly-used formula is that of d'Hondt. Under this formula, the available seats in the council are allocated sequentially, one at a time. The first seat is given to the party with the largest number of votes in the election. Then to allocate each subsequent seat, we divide each party's number of votes by one more than the number of seats that the party has already gotten, and the next seat is given to the party for which this ratio is greatest.
} 
party list to cultivate good reputations for representing all their party's supporters. Thus, allowing voters to approve as many candidates as they want in their chosen party list can help reduce narrow dependency on patron-client relationships. ${ }^{14}$

(One might also consider a non-list approval-voting system in which a voter can approve candidates from many parties, and then the available seats are allocated to the candidates who are approved by the most voters, regardless of party. Such a system would encourage all candidates to cultivate broad popular approval, but it could not guarantee any proportional representation of political minorities. In a union that includes just two villages, for example, if people prefer candidates from their own village then a likely result would be to elect a council entirely from the larger village. Under a proportional-representation list system, however, such a situation would encourage the formation of a new list for the smaller village, whose residents could then get representation in proportion to their size. ${ }^{15}$ )

Allowing major national parties to nominate candidates in local elections gives the national parties a vital interest in supporting the institutions of local democracy and in making sure that local elections are fair. The participation of major parties can make local democracy more competitive, when rival parties sponsor challengers to established local leaders. But I have also argued that competitive local democracy can provide the basis for strengthening national political parties. Any political party must rely on the efforts of its local agents to build popular support in their communities, and these local agents must be motivated by an understanding that their long-term career rewards in the party will depend on some effective measure of their service. The approval-voting open-list elections can provide a particularly effective way for a party to measure the breadth of support that each of its local candidates has helped to bring to the

\footnotetext{
${ }^{14}$ The allocation of seats that are reserved for disadvantaged groups needs some discussion. Under the d'Hondt system (described in the previous footnote), seats are allocated to parties one at a time, and one possibility is that the reserved seats may be allocated last. When some of a party's seats are reserved seats, the allocation of the party's seats to its candidates can be determined by the principle of maximizing the sum of approval votes for all its seated candidates, subject to the constraint that a reserved seat cannot be given to a candidate who is not qualified for it. Such allocations must be feasible if every party list is required to include enough qualified candidates for all reserved seats. But if a party failed to nominate enough qualified candidates to fill its reserved seats, then these seats could be re-allocated to other parties that can fill them, according to the d'Hondt ratio rule.

${ }^{15}$ In the recent SNTV system, the reserved seats for disadvantaged groups can actually reduce the ability of political minorities to get representation in a union council, because each category of reserved seats is elected at large by a separate non-transferable vote, with fewer seats than in the unreserved category. In contrast, the reserved seats in the National Assembly are elected by list PR, and so they can increase representation for dispersed minority parties that cannot win many seats by plurality voting.
} 
party. Thus, a party can be strengthened when its local activists know that their political advancement may depend on their success in local elections. The promotion of successful local candidates might reduce the importance of personal loyalty to superiors in the party hierarchy, as an alternative criterion for political advancement. But party leaders who recognize the contributions of their successful local candidates should be rewarded by a stronger and more competitive party.

We have focused on local council elections because they can provide the primary route for thousands of local leaders to enter democratic politics, thus lowering political barriers to entry and strengthening the entire democratic system. The significance of these local councils has been substantially reduced, however, by the system of giving executive authority to a local union nazim (or mayor) who is separately elected (in a joint ticket with the assistant naib nazim). When one local official's election matters so much more than all the others, the basis of local democracy becomes narrower. So to strengthen the local base of democracy, I would suggest that local councils should be given the power to elect and replace their local nazim, instead of having nazims separately elected. That is, the arguments for parliamentary democracy should be applied equally to local governments at all levels, including the local union governments as well as the larger units of local government at the tehsil and district levels. ${ }^{16}$

At the district level of government, under the recent rules, the district council is formed by the nazims of all local unions within the district, plus a small number of other representatives elected by the union councilors. This system of constituting district governments from union governments seems well designed to encourage cooperation between the different levels of local government. Certainly, a district nazim should have a strong incentive to maintain cooperative relationships with the local union nazims when they are members of the district council that elects him. But I would suggest that the district council should also include some representatives who are elected at large by the voters of the whole district, using the approval-voting open-list proportional representation system. Even if these at-large representatives constituted only a

\footnotetext{
${ }^{16}$ Under the recent local government system, the union councilors in a district together elected their district nazims, but the nazim thereafter was not responsible to these councilors. Vote-buying may have been more problematic in these nazim elections than in a normal parliamentary system because the union councilors were not subject to any party discipline (given the Musharraf regime's restrictions against parties in local politics) and because the union councilors were electing a leader over whom they would subsequently have no influence. It would be more difficult for councilors to corruptly sell their votes for electing a nazim if the councilors could subsequently replace the nazim at any time.
} 
small fraction of the district council, they could make a vital contribution to district politics, as representatives with broad approval from voters throughout the district. It would be natural to suggest that the district nazim should be chosen by the district council from among these at-large representatives. Then the position of at-large representative in a district council could become an important step in the ladder of democratic advancement (between local union councils and provincial assemblies) for politicians who earn the trust of voters in the district.

\section{Problems of plurality voting in national and provincial elections}

General seats in Pakistan's National Assembly and provincial assemblies are elected in districts, where each district elects a representative to fill one seat in the assembly. (A small fraction of the seats, those reserved for women and minorities, are allocated by proportional representation based on the allocation of general seats.) The simple plurality or "first past the post" system of election in single-seat districts has been widely used in many countries throughout the world, but it creates substantial barriers against the entry of more than two serious parties in any district. In India before 1967, for example, the Congress party could regularly win over $70 \%$ of the legislative seats with less than $48 \%$ of the vote as long as the opposition votes were split among many parties' candidates (Guha, 2008, p. 420). For the opposition's popular support to be expressed effectively in plurality elections, the various opposition parties had to negotiate agreements to have only one among them competing in each district. In any other competitive market, such agreements to restrict competition would be considered a conspiracy against the public, but in plurality elections such noncompetition agreements are considered responsible political leadership. In plurality elections, voters must be focused on two serious candidates, with an understanding that a vote for any other candidate would be wasted, as it could not influence the serious race.

There may be some advantages to organizing the great issues of politics into a simple choice between two parties, each of which offers a coherent political plan aimed at a majority of voters. But the strong incentive against supporting third-parties candidates in plurality elections should be recognized as a political entry barrier that weakens democratic competition.

To permit more flexibility in the number of serious candidates who can compete to represent a single-seat district, one could suggest a two-round runoff system, in which a second election is held if no candidate gets a majority of the votes in the first round. The candidate with 
the most votes in the second round wins the seat, as in plurality voting, and so voters generally focus on two serious candidates in the second round, but more candidates can be seriously considered in the first round. In French assembly elections, any candidate with over 1/8 of the first-round vote can compete in the second-round runoff, but the voters generally understand that the first-round results determine which two candidates are serious contenders in the second round. ${ }^{17}$ One could also suggest an instant-runoff election, in which voters rank the candidates, ballots are counted as votes for the top-ranked candidate, then are recounted iteratively after eliminating low-scoring candidates and transferring their votes to the next-ranked candidate.

An alternative system that I would suggest is approval voting, where a voter can approve any number of candidates (but giving just one approval vote to each) and the candidate who is approved by the most voters in the district wins the district's seat. Approval voting would allow more than two serious candidates to compete for broad popular support in the center of the political spectrum, but it has not yet been widely applied.

If a change from single-seat districts can be considered, I could also suggest open-list proportional representation in small districts that have (say) three seats for each district. Just as plurality voting in single-seat districts can deter voters from seriously considering more than two parties, so proportional representation in districts with $\mathrm{M}$ seats tends to deter voters from focusing on more than $\mathrm{M}+1$ parties. (This $\mathrm{M}+1$ rule has been analyzed by Cox, 1997.) So when each district has three seats, the number of serious parties in any region could range from two to four, which could enable the democratic system to respond more flexibly to new political forces.

\section{Broader regional connections}

In recent decades, democracy in Europe has been consolidated by a system of gradually expanding political and economic ties between neighboring nations based on their shared commitment to democracy. Such a plan might also be worth suggesting to consolidate democracy in Pakistan and Afghanistan. A joint commission could explore ways to build democratic political ties between Pakistan and Afghanistan, even if the prospect of a federation or union between them might seem as remote as it once seemed between France and Germany.

\footnotetext{
${ }^{17}$ The serious candidates at the second round are usually the two who got most first-round votes, but not always. With 3 leftist and 2 rightist candidates, for example, if the two rightists scored highest in the first round then the voters might focus in the second round on the strongest rightist against the strongest leftist. Party primaries in America have a similar function to first-round elections in France.
} 
Ideally, such a system of regional political integration could be extended to include all democratic nations in the Southern Asian Association for Regional Cooperation. The essential key is that political connections should be formed gradually, in small steps, and that each nation's participation should be conditional on its retaining a democratic system of government.

Afghanistan established a presidential form of democracy in 2004, and then in 2005 it used the flawed SNTV form of proportional representation in its legislative elections. As we have seen, presidentialism and SNTV both discourage the formation of strong political parties. Perhaps these constitutional structures were adopted precisely because they are so bad for political parties, as President Hamid Karzai reportedly hoped that democracy could be established in Afghanistan without strong parties, which Ahmed Rashid (2008, p. 258) has called Karzai's biggest mistake. Democracy was going to be difficult enough to establish in Afghanistan, but its chances of success could have been greater with a well-designed constitutional system. Parties become channels of political privilege (and perhaps that is why Karzai might have considered them distasteful), but such channels are essential to mobilize a network of agents who have vested interests in sustaining democratic government. For healthy democracy, I have argued, the goal is not to abolish parties but to make sure that there are at least two strong national parties, each of which includes many politicians with good reputations for public service, and that new parties with new leadership can develop when old parties do not meet voters' expectations. Afghanistan's experiment with centralized nonparty presidential government has been a tragic disaster for that desperately poor country, which deserved a better chance for successful democracy. Now Pakistan may have the best opportunity to positively influence its northern neighbor by cultivating shared aspirations for Islamic federal democracy in both nations.

Democratic governments are established, not by development assistance nor by military operations, but by political parties. Even the great counterinsurgency theorist David Galula (1964) observed that the essential goal of counterinsurgency is to build a political machine from the population upward, and that political machines are networks of patronage. Military operations can contribute to the establishment of democracy only when their mission is to protect local agents of democratic parties and government as they extend their political networks into every community. In such a mission, cooperation with elected local councils can be vital. Unfortunately, recent military operations against insurgents in Tribal Areas have not been 
followed by reforms to build local democratic governance there.

\section{Conclusions}

Democracy is worth cultivating because the competitive rules of the political game can affect the behavior of political leaders, who determine the performance of government in service to the public. The constitutional allocation of powers and the electoral system define the rules of the game in a democracy. Any change in these constitutional rules could affect the chances for democracy to pass its ultimate test of delivering better government services for the public. Understanding the importance of current efforts to consolidate effective democracy in Pakistan, I have tried here to suggest various ways that the rules of the political game in Pakistan might be reformed to increase incentives for effective democratic competition.

The challenges to democracy in Pakistan are formidable. Intervals of military rule have ended with recognition that effective stable government must be based on civilian political organizations that are widely trusted by the voters. Now many areas of Pakistan are threatened by violent guerrilla forces, and such insurgencies can be defeated only by effective cooperation between national military forces and local political leaders who are trusted by their communities. Thus, the nation urgently needs its political parties to develop broad networks of national and local leaders who have earned the trust of voters throughout the nation. In particular, the Tribal Areas should not be excluded from the nation's democratic political system.

So the most important suggestions here may be those for fostering strong local democracy. I have suggested electing local councils by a system of open-list proportional representation with approval voting, as a mechanism for inducing parties to strengthen their base of local democratic leadership in all communities. Such local democratic leadership should become a primary source of candidates who can advance democratically to higher offices, after first proving their ability to earn popular approval at the local level.

Other suggestions here have been aimed at strengthening the principle of parliamentary responsibility in government, to foster cohesive assembly-based parties. To reduce barriers against new parties, I have argued that members of the National Assembly should be free to change parties, and I have suggested that runoffs or approval voting could allow voters to consider third-party candidates more seriously in assembly elections. In Pakistan's federal system, local and provincial democracy also help to reduce political entry barriers, by creating 
opportunities for responsible leadership which can qualify politicians to become candidates for power at higher levels. But there may be advantages to subdividing provinces that contain too large a portion of the national population.

The analysis here has been based on a perception that successful democracy requires a flexible system of strong competitive parties and a plentiful supply of candidates who have good reputations for responsible public service. The details of such suggestions are important, and they should be subject to much more scrutiny and debate. My essential point is that parliamentary government, federalism, local democracy, and open-list electoral systems should be seriously considered as constitutional structures for lowering entry barriers into politics and for developing the nation's supply of responsible democratic leadership.

\section{REFERENCES}

Barry Ames, The Deadlock of Democracy in Brazil (U Michigan Press, 2001).

Pranab Bardhan and Dilip Mookherjee, editors, Decentralization and Local Governance in Developing Countries (MIT Press, 2006).

Carles Boix, Democracy and Redistribution (Cambridge U Press, 2003).

Dawn Brancati, "Decentralization: fueling the fire or dampening the flames of ethnic conflict and secessionism?" International Organization 60:651-685 (2006).

Ali Cheema, Asim Ijaz Khwaja, and Adnan Qadir, "Local government reform in Pakistan: context, content, and causes," in Bardhan and Mookherjee (2006), pp 257-284.

Ali Cheema, Adnan Q. Khan, and Roger Myerson, "Breaking the counter-cyclical pattern of local democracy in Pakistan" home.uchicago.edu/ rmyerson/research/pakdemoc.pdf (2010).

Gary W. Cox, Making Votes Count (Cambridge U Press, 1997).

David Galula, Counterinsurgency Warfare (Praeger, 1964).

Ramachandra Guha, India after Gandhi (NY: Harper Collins, 2008).

Henry E. Hale, "Divided we stand: institutional sources of ethnofederal state survival and collapse," World Politics 56(2):165-193 (2004).

Philip E. Keefer, Ambar Narayan, and Tara Vishwanath, "Decentralization in Pakistan: are local governments likely to be more accountable than the central government," in Bardhan and Mookherjee (2006), pp 285-303. 
Andrew Konitzer, Voting for Russia's Governors (Johns Hopkins University Press, 2006).

Robert Michels, Political Parties: A Sociological Study of Oligarchic Tendencies in Modern Democracy (NY: Hearst, 1915).

Roger Myerson, "Theoretical comparison of electoral systems," European Economic Review 43:671-697 (1999).

Roger Myerson, "Federalism and incentives for success of democracy," Quarterly Journal of Political Science 1:3-23 (2006).

Adam Przeworski, Michael E. Alvarez, Jose Antonio Cheibub, Fernando Limongi, Democracy and Development (Cambridge U Press, 2000).

J. Mark Ramseyer and Frances M. Rosenbluth, The Politics of Oligarchy: Institutional Choice in Imperial Japan (Cambridge U Press, 1998), chapter 4.

Ahmed Rashid, Descent into Chaos (NY: Viking Penguin, 2008).

Daniel Triesman, The Architecture of Government: Rethinking Political Decentralization (Cambridge U Press, 2007).

AUTHOR'S ADDRESS:

Roger Myerson, Economics Department, University of Chicago, 1126 East 59th Street, Chicago, IL 60637.

Phone: 1-773-834-9071. Fax: 1-773-702-8490. Email: myerson@uchicago.edu

Web site: http://home.uchicago.edu/ rmyerson/

This paper: http://home.uchicago.edu/ rmyerson/research/lahore.pdf

[originally written April 2009, last revision Feb 2012] 